\title{
Die hantering van teenoorgesteldheid in enkele tipes woordeboeke, toegelig met Afrikaanse voorbeelde
}

\author{
Anna Nel Otto, Departement Afrikaans en Nederlands, Nelson Mandela \\ Metropolitaanse Universiteit, Vistakampus, Port Elizabeth, Republiek van \\ Suid-Afrika (annanel.otto@nmmu.ac.za)
}

Opsomming: Hoewel teenoorgesteldheid tot dusver deur baie leksikograwe as 'n bonus beskou is in die meeste tipes woordeboeke, word in hierdie artikel aangevoer dat hul insluiting verpligtend behoort te wees in aanleerderwoordeboeke en dat dit ook van groot nut kan wees in verskeie ander tipes woordeboeke. Eers word 'n uiteensetting gegee van verskillende tipes teenstellingsverhoudings. Daarna word die hantering van teenoorgesteldheid toegelig met Afrikaanse voorbeelde, in drie tipes woordeboeke bespreek met betrekking tot twee kategorieë: inligting in die toeligtingsgedeelte en in die alfabetiese gedeelte.

Met verwysing na die pluspunte sowel as die tekortkominge in die bespreekte woordeboeke, word voorstelle ter verbetering van die hantering van teenoorgesteldheid in hierdie woordeboeke gemaak, bv.: (1) die term teenoorgesteldheid behoort duidelik omskryf te word in die toeligtingsgedeelte, (2) die leksikale items waarby teenoorgesteldes aangedui kan word, behoort as lemmas op hulle alfabetiese plekke opgeneem te word, (3) die teenoorgesteldes van hierdie lemmas behoort by dié lemmas aangedui te word, en (4) die mees frekwente teenoorgesteldes kan deur middel van korpusontleding geïdentifiseer word.

Sleutelwoorde: AANLEERDERWOORDEBOEK, ALFABETIESE GEDEELTE, ANTONIMIE, DEFINIËRING, EENTALIGE WOORDEBOEK, KRUISVERWYSINGS, LEKSIKOGRAFIE, LEMMA, SEMANTIESE OPPOSISIE, TEENOORGESTELDHEID, TOELIGTINGSGEDEELTE, TWEETALIGE WOORDEBOEK

\begin{abstract}
The Treatment of Opposites in a Few Types of Dictionaries, Illustrated by Afrikaans Examples. Although lexical items indicating semantic opposition have, until now, been regarded by many lexicographers as a bonus in most types of dictionaries, it is argued in this article that their inclusion should be compulsory in learner's dictionaries and that it can also be of great value in many other types of dictionaries. First an exposition is given of different types of semantic opposition. Then the treatment of opposition illustrated by Afrikaans examples, is discussed in three types of dictionaries by looking at two categories: the information in the usage guide and in the alphabetical part.

With reference to the strong points as well as the shortcomings in the discussed dictionaries, suggestions are made for the improvement of the treatment of semantic opposition in these dictionaries, e.g. (1) the term semantic opposition should be clearly defined in the usage guide, (2) the
\end{abstract}


lexical items indicating semantic opposition should be recorded in their alphabetical places as lemmata, (3) the opposites should be indicated at these lemmata, and (4) the most frequent opposites can be identified by using a corpus analysis.

Keywords: ALPHABETICAL PART, ANTONYMY, ANTONYMOUS RELATIONS, BILINGUAL DICTIONARY, CROSS-REFERENCES, DEFINING, LEARNER'S DICTIONARY, LEMMA, LEXICOGRAPHY, MONOLINGUAL DICTIONARY, SEMANTIC OPPOSITION, USAGE GUIDE

\section{Inleiding}

In die breër konteks van die leksikale semantiek maak antonimie deel uit van verskeie ander leksikale betrekkinge waarvan sinonimie, polisemie, homonimie en hiponimie as die bekendste semantiese verhoudings beskou word. Antonimie word in leketaal dikwels as oorhoofse term en sinoniem vir "teenoorgestelde betekenis" gebruik (Gouws 1989: 158).

Ofskoon antonimie ' $n$ natuurlike en vaste leksikale betrekking van taalstruktuur is, is daar volgens Palmer (1976: 78) tog 'n merkbare verskil in die status wat sinonimie en antonimie relatief ten opsigte van mekaar beklee. Hy beweer dat hierdie verskil in status veral sigbaar is in soverre antonimie in semantiekhandboeke soms minder aandag geniet, en in die meeste gevalle selfs geen plek in woordeboeke vind nie.

In hierdie artikel sal daar egter geprobeer word om aan te toon dat die insluiting van teenoorgesteldes nie op 'n lukrake wyse gehanteer behoort te word nie en dat dit, indien konsekwent aangedui, van groot waarde vir die woordeboekgebruiker kan wees. Vergelyk hier ook Gouws (1990: 58), wat tereg daarop wys dat daar nie op 'n gedetailleerde wyse aangedui hoef te word watter tipe teenstelling van toepassing is nie. Hy stel voor dat die leksikograaf 'n generiese etiket soos OPP gebruik om die mikrostrukturele elemente wat semantiese teenoorgesteldes van 'n lemma verteenwoordig, aan te dui.

Een van die kenmerke wat Nation (2001: 295) as belangrik beskou ten einde die gepaste woord in 'n aktiewe aanleerderwoordeboek te vind, is: "See if the dictionary provides opposites, synonyms, superordinates and other related words as part of an entry." Met betrekking tot aanleerderwoordeboeke ondersteun Moulin (1983: 149) onder andere kruisverwysings na sinonieme, teenoorgesteldes, e.s.m. by vertaalekwivalente, wat die leerder sal aanmoedig om paradigmatiese ondersoeke te doen. Paradis en Willners (2006) argumenteer dat woordeboeke oor die algemeen, maar veral aanleerderwoordeboeke, belangrike instrumente is by die aanleer van vreemde tale. Antoniemoefeninge kom algemeen voor in taalaanleerkurrikula en kennis van antonimie is 'n noodsaaklike deel van tekstuele kompetensie (Halliday en Hasan 1976). Jones (2002: 118-119) raam dat een uit elke vyftig sinne 'n antoniempaar bevat en het ook soortgelyke resultate vir gesproke Engels gevind (vgl. Jones 2006).

Aangesien semantiekteorie 'n goeie basis vir die leksikografie is, word daar eerstens ' $n$ teoretiese bespreking van die verskillende teenstellingsbetrek- 
kinge aangebied. Daarna word dit opgevolg met 'n toegepaste ondersoek na die hantering van hierdie betrekkinge in 'n drietal verskillende woordboektipes.

\section{2. 'n Uiteensetting van verskillende teenstellingsbetrekkinge}

\subsection{Antonimie}

Volgens De Stadler (1989: 81 e.v.) is daar verskillende tipes teenoorgesteldheid, waarvan antonimie maar een is.

Die meeste linguiste definieer antonieme in terme van gradeerbaarheid by adjektiewe (vgl. Palmer 1976, Lyons 1977, Lehrer en Lehrer 1982, Cruse 1986 en De Stadler 1989).

(a) De Stadler (1989: 82) wys daarop dat verskeie kenmerke van antonieme voortvloei uit die feit dat hulle gradeerbaar is:

(i) Hulle kan trappe van vergelyking neem, bv. mooi, mooier en kort, korter, ens.

(ii) Hulle kan met graadwoorde verbind, bv. baie mooi, te kort, ens.

(iii) Indien die een gestel word, word die ander ontken, bv. Sy is lank impliseer Sy is nie kort nie, maar die omgekeerde is nie waar nie: die ontkenning van die een beteken nie noodwendig dat die ander daarmee gestel word nie: Sy is nie kort nie impliseer nie noodwendig Sy is lank nie.

(iv) Eksplisiete of implisiete gradering (vergelyking in terme van 'n norm) kom altyd voor. Daarom beteken Ons huis is groot eintlik "Ons huis is groter as die normale huis".

(v) Antoniempare het 'n positiewe en 'n negatiewe pool. Die positiewe pool verteenwoordig die ongemerkte waarde van die betrokke eienskap. By die eienskap hitte, is die positiewe pool byvoorbeeld warm en die negatiewe pool koud.

(b) Volgens Muehleisen (1997: 8) het antonieme ook die eienskap "committedness", hier vertaal as "geïmpliseerde waarde". 'n Adjektief het 'n geïmpliseerde waarde indien dit ' $n$ bepaalde waarde impliseer wanneer dit in 'n vraag gebruik word, en dit is "impartial/uncommitted", hier vertaal as "neutraal", indien dit nie so 'n implikasie het nie. Lank is byvoorbeeld neutraal in 'n vraag soos Hoe lank is Jan? Hierdie vraag is neutraal en kan gebruik word ongeag of die spreker Jan se benaderde lengte ken en ongeag of Jan lank, kort of van gemiddelde lengte is. Hierteenoor het die adjektief kort 'n geïmpliseerde waarde. 'n Spreker sal slegs vra Hoe kort is Jan? as daar rede is om te glo dat Jan korter is as die normale lengte. 
(Vgl. ook De Stadler 1989: 83.) Muehleisen (1997: 8) wys verder daarop dat baie pare gradeerbare antonieme een item met 'n geïmpliseerde waarde en een neutrale term bevat, bv. oud $\mathrm{x}$ jonk, swaar $\mathrm{x}$ lig, vinnig $\mathrm{x}$ stadig, maar baie ander pare bevat weer twee items met geïmpliseerde waardes, bv. onskuldig $\mathrm{x}$ skuldig, mooi $\mathrm{x}$ lelik, gelukkig $\mathrm{x}$ hartseer, ens.

(c) Gemerktheid is volgens Muehleisen (1997: 8) 'n sambreelterm vir verskeie verwante verskynsels wat die gemerkte lid van 'n antoniempaar van die ongemerkte lid onderskei. Lehrer (1985) bespreek verskeie kriteria wat voorgestel is om gemerktheid te definieer. Geïmpliseerde waarde is een van hulle: die neutrale lid van 'n antoniempaar word as ongemerk beskou en die lid met geïmpliseerde waarde gemerk is, gevolglik is oud ongemerk, terwyl jonk gemerk is. Indien die naam van die semantiese skaal morfologies verband hou met een van die antonieme, dan is dit verwant aan die ongemerkte lid, bv. die naam van die skaal vir lengte is verwant aan die ongemerkte lank eerder as die gemerkte kort.

Nog 'n kenmerk van gemerktheid is dat die ongemerkte antoniem oor die algemeen in 'n wyer reeks sintaktiese kontekste kan optree; ongemerkte antonieme veral kan met maatfrases voorkom, maar gemerktes gewoonlik nie. So kan 'n mens byvoorbeeld sê iets is drie meter lank, maar nie drie meter kort nie. Soortgelyk is verhoudings gewoonlik slegs moontlik met die ongemerkte antoniem; ' $n$ mens kan sê Karin is twee keer ouer as Petro, maar nie Petro is twee keer jonger as Karin nie. Morfologie speel ook ' $n$ rol: in pare waarin een antoniem afgelei is van die ander, word gesê dat die afgeleide lid gemerk is, dus is gelukkig ongemerk en ongelukkig gemerk.

(d) Volgens De Stadler (1989: 83) veronderstel gradeerbaarheid verskillende waardes op 'n skaal, dikwels nie net twee soos wat deur 'n antoniempaar veronderstel word nie. ' $n$ Mens kan jouself dan afvra watter waardes op 'n skaal as teenoorgesteldes van mekaar beskou kan word. Hy bespreek die semantiese veld rondom die antoniempaar baie en min deur na die volgende woorde te verwys: oorvloedig, volop, baie, heelwat, genoeg, bietjie, min, weinig, niks. Die woord genoeg kan waarskynlik as die middelpunt van die skaal beskou word en op grond hiervan kan antonimie gedefinieer word as "twee punte op 'n skaal van gradeerbares op gelyke afstande aan weerskante van die middelpunt". Gevolglik kan die volgende items antoniempare wees: oorvloedig $\mathrm{x}$ niks, volop $\mathrm{x}$ weinig, baie $\mathrm{x}$ min en heelwat $\mathrm{x}$ bietjie. Hierdie voorlopige definisie kan egter nie korrek wees nie, aangesien die volgende pare ook as teenoorgesteldes beskou kan word: genoeg $\mathrm{x}$ oorvloedig, volop $\mathrm{x}$ bietjie, baie $\mathrm{x}$ weinig, heelwat $\mathrm{x}$ min, oorvloedig $\mathrm{x}$ bietjie. De Stadler (1989: 84) kom dan tot die gevolgtrekking dat antonieme nie noodwendig reglynige teenoorgesteldes op 'n skaal is nie, maar op verskillende afstande van die middelpunt af kan lê, en selfs in 'n ver- 
houding van antonimie met die middelpuntterm self kan tree. Die enigste kriterium is dat die lede van 'n antoniempaar aan weerskante van of op die middelpunt van die skaal moet lê.

(e) De Stadler (1989: 84) wys daarop dat die feit dat 'n leksikale item verskillende polisemiese waardes (of kombinatoriese waardes) kan hê, ook daartoe lei dat daar vir een woord verskillende teenoorgesteldes aangebied kan word. Vergelyk byvoorbeeld die verskillende polisemiese waardes van die woord soet.

(i) wat ' $n$ aangename suikersmaak het: soet water (sout, brak), soet patats (sout), soet verversings (sout), soet koffie (bitter), soet druiwe (suur), soet wyn (droë)

(ii) baie aangenaam, veral vir die gehoor en vir die reuk: soet tone (wanklinkende), soet geur (walglike), soet drome (slegte, nare)

(iii) gehoorsaam, nie stout nie, volgsaam: soet kind (stout, ongehoorsame)

Uitdr. Die soet en suur van die lewe

\subsection{Ander tipes teenoorgesteldheid}

\subsubsection{Binêre opposisies}

Die tipe teenstelling wat die grootste mate van ooreenkoms met antonieme het, is komplementêre pare. Cruse (1986: 198) beskryf laasgenoemde soos volg: "The essence of a pair of complementaries is that between them they exhaustively divide some conceptual domain into two mutually exclusive compartments, so that what does not fall into one of the compartments must necessarily fall into the other." De Stadler (1989: 84) wys dan ook tereg daarop dat komplementêre pare nie gradeerbaar is nie en indien die een gestel word, word die ander ontken, en indien die een ontken word, word die ander gestel: $\mathrm{Hy}$ is manlik impliseer naamlik Hy is nie vroulik nie en Daardie persoon is nie manlik nie impliseer Daardie persoon is vroulik.

Dit is wel so dat vroulik soms gradeerbaar is (vrouliker, vroulikste), maar hierdie gradeerbaarheid vloei voort uit die verskillende polisemiese waardes van die betrokke leksikale item, in Engels geleksikaliseer as female en feminine onderskeidelik (De Stadler 1989: 85). Hieruit blyk dat verskillende polisemiese waardes van dieselfde leksikale item selfs in verskillende tipes teenoorgesteldheid gevind kan word.

'n Volgende tipe teenstellingsbetrekking is omgekeerdheid. By woordpare soos man $\mathrm{x}$ vrou, vader $\mathrm{x}$ seun, vader $\mathrm{x}$ dogter, dokter $\mathrm{x}$ pasiënt, bo $\mathrm{x}$ onder en koop $\mathrm{x}$ verkoop kry 'n mens voorbeelde van omgekeerdheid (De Stadler 1989: 85). 
Omgekeerdheid geld op sinsvlak. Indien $X$ 'n pasiënt is van $Y$, dan moet $Y$ die dokter wees van $X$. Die een lid ontken nie die ander lid nie, maar impliseer juis dat dit bestaan. (Vgl. Cruse 1986: 231.)

'n Laaste tipe teenstelling is ruimtelike opposisie. Ruimtelike opposisie kom voor waar daar ' $\mathrm{n}$ verandering van toestand of plek is, bv. op $\mathrm{x} a$ f, in $\mathrm{x}$ uit, kloksgewys $\mathrm{x}$ antikloksgewys, maar ook woorde soos vasmaak $\mathrm{x}$ losmaak, trou $\mathrm{x}$ skei en verskyn $\mathrm{x}$ verdwyn.

\subsubsection{Opposisie en kontras: verenigbaarheid en onverenigbaarheid}

In die voorafgaande afdeling is gewerk met binêre opposisies. Telkens is daar gewys op teenoorgesteldheid van leksikale items se betekenisse met verwysing na woordpare.

Daar bestaan egter ook ander verhoudings in die leksikon wat onder die dekterm kontras kan ressorteer en wat nie-binêre kontraste verteenwoordig. De Stadler (1989: 86) verdeel hierdie kontraste in verenigbare en onverenigbare kontraste.

In die geval van verenigbare kontraste kan die leksikale versamelings almal beskou word as ko-hiponieme van dieselfde superordinaat; so dui noord, suid, oos, wes, ens. almal op rigtings. Vergelyk ook die dae van die week, maande van die jaar, seisoene, kleure, verskillende tipes diere, bome, vrugte, groente, blomme, ens.

Binne hier versamelings verenigbares is daar woordpare wat as teenoorgesteldes (d.w.s. binêre opposisies) van mekaar beskou kan word. By die kleure kan swart byvoorbeeld as die teenoorgestelde van wit beskou word.

Teenoor die verenigbares staan die onverenigbares, soos in die volgende voorbeeld waar die items se betekenisse onverwant is: kind, hardloop, vinnig.

Idiomatiese teenoorgesteldes vind 'n mens by woordpare soos tee $\mathrm{x} k$ koffie, sout $\mathrm{x}$ peper, mes $\mathrm{x}$ vurk, vis $\mathrm{x}$ skyfies, koppie $\mathrm{x}$ piering, wat ook verstenings genoem word.

Hierdie woordpare word tradisioneel as teenoorgesteldes van mekaar beskou, hoewel hulle dit logies gesien nie is nie (De Stadler 1989: 87).

\subsection{Kwasi-teenoorgesteldes}

Cruse (1986) en Lehrer en Lehrer (1982) bespreek kwasi-teenoorgesteldes. Cruse beskryf onsuiwer teenoorgesteldes as teenoorgesteldes wat in hul betekenis ' $n$ meer elementêre teenoorgesteldheid omvat of insluit. Cruse (1986: 198) sê byvoorbeeld: "Giant: dwarf can be said to encapsulate the opposition between large and small (but this opposition does not exhaust their meaning); likewise, shout and whisper encapsulate loud and soft, criticize and praise encapsulate good and bad." 


\subsection{Kriteria vir teenoorgesteldes (vs. kwasi-teenoorgesteldes)}

Die volgende kriteria vir teenoorgesteldes is deur Cruse (1986) en Lehrer en Lehrer (1982) voorgestel:

(a) Suiwerheid van die semantiese opposisie: In sommige pare kwasi-teenoorgesteldes (bv. fluister x skreeu) put die semantiese opposisie nie die betekenis van die woorde uit nie. Die implikasie is dat die semantiese kontras in prototipiese pare teenoorgesteldes in 'n sekere sin die betekenisse van die woorde uitput.

(b) Maklike waarneming van 'n semantiese dimensie: Met kwasi-teenoorgestelde pare soos dorp $\mathrm{x}$ platteland, is dit moeilik om te bepaal wat die relevante semantiese dimensie kan wees. Die implikasie is dat die semantiese dimensie maklik geïdentifiseer kan word vir prototipiese teenoorgesteldes.

(c) Ooreenkoms ten opsigte van nieproposisionele betekenis: Sommige kwasiteenoorgesteldes (bv. plomp x uitgeteer) het baie verskillende konnotasies. Die implikasie is dat prototipiese teenoorgesteldes baie eenders is in terme van nieproposisionele betekenis.

(d) Afstand vanaf die middelpunt van 'n semantiese dimensie: In sommige gevalle lyk dit asof een lid van 'n paar van kwasi-teenoorgesteldes (bv. afskuwelik) 'n meer ekstreme waarde as die ander lid (lelik) het. Die implikasie is dat prototipiese teenoorgesteldes op gelyke afstandpunte van ' $n$ middelpunt lê.

(e) Ooreenkoms in verspreiding: By beide big en sy antoniem little kan verwys word na relatiewe ouderdom eerder as fisiese grootte in konstruksies soos big sister en little brother, maar die kwasi-teenoorgestelde van little, dit is large kan net verwys na fisiese grootte saam met die s.nwe. sister en brother.

Opposisiebetrekkinge kan op verskillende vlakke voorkom: leksikaal soos reeds aangedui, subleksikaal soos in die volgende twee paragrawe, asook multileksikaal, bv. Hy/Sy is ouer as gister $\mathrm{x}$ Hy/Sy het nie buskruit uitgevind nie. Sodanige betrekkinge kan ook oor die grense van leksikale status heen reik, soos in die geval van Hy/Sy is slim $\mathrm{xHy/Sy}$ het nie buskruit uitgevind nie.

Teenstellende korrelasies kom ook by morfologiese boustukke voor: in- $\mathrm{x}$ uit-, hoof- x by-,-vriendelik x -onvriendelik.

Teenstellende leksikale items kan verder op grond van struktuur in verskillende soorte verdeel word. Hulle kan in leksikale (open x sluit) en morfoleksikale (oopmaak $\mathrm{x}$ toemaak) tipes verdeel word. By die morfoleksikales lê die 
teenstellende elemente in die morfologiese bouelemente: by affikse: antedateer $\mathrm{x}$ postdateer, of met 'n nulplek: vriendelik x onvriendelik, en by die suffikse: stemhebbend $\mathrm{x}$ stemloos. Dan is daar ook nog die kompositumteenstellings, waar kompositum in die wydste sin bedoel word. Die teenstelling is óf by die eerste element (blyspel x treurspel) óf by die tweede element (belastingverhoging $\mathrm{x}$ belastingverlaging). In uitsonderlike gevalle kom die teenstelling by beide elemente voor: afstoot x aantrek. (Vgl. Müller 1989: 2794-2795.)

Een betekeniswaarde van 'n leksikale item het in die meeste gevalle net een antoniem (sterk $\mathrm{x}$ swak); dit is veral waar ten opsigte van die morfoleksikale woorde (ingaan $\mathrm{x}$ uitgaan). Soms is daar egter meer as een antoniem: sowel by leksikale antoniempare (koud x warm, heet) as by morfoleksikale items (gemeng): mobiel x immobiel, onbeweeglik. (Vgl. Müller 1989: 2794-2795.) Hier moet naamlik onderskei word tussen 'n teenstellingswoord, waar daar formele ooreenstemming is, soos by mobiel $\mathrm{x}$ immobiel, teenoor onbeweeglik wat nie vormlik ooreenstem nie en slegs ' $n$ teenstellingsveldwoord is.

\section{Die gebruik van antonieme in verskillende tipes woordeboeke}

Teenstellings kan van groot nut wees in minstens die volgende tipes woordeboeke: eentalige verklarende woordeboeke, tweetalige woordeboeke, en eentalige antoniemwoordeboeke of sinoniemwoordeboeke met antonieme. In die volgende drie afdelings sal die behandeling van teenstellings in elkeen van hierdie tipes woordeboeke bespreek word, toegelig met Afrikaanse voorbeelde in soverre hulle voorhande is.

\subsection{Eentalige verklarende woordeboeke}

Hierdie tipe woordeboeke, wat onder andere omvattende woordeboeke, standaardwoordeboeke en aanleerderwoordeboeke kan insluit, bied sinonieme en teenstellings aan as deel van hulle semantiese inligting of selfs as die enigste semantiese inligting (vgl. Bergenholtz en Tarp 1995: 126). Die aanbieding van teenstellings sal ondersoek word in die Woordeboek van die Afrikaanse Taal (voortaan WAT), die Handwoordeboek van die Afrikaanse Taal (voortaan HAT) en die Basiswoordeboek van Afrikaans (voortaan BWA) onderskeidelik.

Sedert die verskyning van die eerste deel van die WAT het daar 'n merkbare verbetering in die hantering van inligting oor teenoorgesteldes in die toeligtingsgedeelte ingetree. Raidt (1993: 217) wys reeds ten opsigte van die agtste deel van die WAT daarop dat byvoorbeeld die hantering van sinonieme en antonieme in die toeligtingsgedeelte uiteengesit word. Feinauer (1996: 260) wys ook daarop dat die WAT bedag is op sensitiwiteit rondom geslag. Vroulike vorms in geslagsopposisiepare word dus wel gelemmatiseer en volledig bewerk in WAT IX. Nietemin kom daar nog enkele inkonsekwente gevalle voor (vgl. Feinauer 1996: 262). 
In die toeligtingsgedeelte van deel I is teenstellings nie verklaar nie en daar is ook nie aangedui of en hoe hierdie tipe semantiese betrekking in die WAT gehanteer word nie. In die toeligtingsgedeelte van die jongste deel, deel XII, vind ' $\mathrm{n}$ mens nie die term antonimie nie, maar wel semantiese opposisie, wat dus op 'n wyer bestek dui. Dit word soos volg omskryf:

'n Aanduiding van semanties teenstellende en maklik met die lemma verwarbare leksikale items. Die formules wat hier gebruik word, is "teenoor" vir semanties teenstellende leksikale items of "onderskei van" vir leksikale items wat maklik met die lemma verwar kan word, bv. onder normaalhorend: teenoor gehoorgestrem, en onder oumawoonstel: onderskei van eenmanswoonstel. Vgl. verder paragraaf 5.4.

In paragraaf 5.4 word dan aangedui waar en hoe teenoorgesteldes opgeneem word:

Kruisverwysing na formele antonieme en verwante of maklik verwarbare leksikale items vind deur middel van vermelding by die onderskeie leksikale items plaas. Hierdie vermelding van die sogenaamde semantiese teenstellings en verwante vorme dien as inligting dat die leksikale item ' $n$ bepaalde antoniem het.

Die semantiese teenstellings en verwante vorme word vermeld na die definisie, maar indien daar sinonieme is, dan na die sinonieme, en word voorafgegaan deur 'n kommapunt. Antonieme en ander semanties teenstellende vorme soos komplementêre leksikale pare word deur die term "teenoor" aangedui, terwyl vorme wat soms met die lemma verwar word deur die term "onderskei van", met of sonder verdere kwalifikasies, voorafgegaan word. Leksikale items wat betekenismatig redelik na aan die lemma is, maar nie as sinoniem daarvan beskou kan word nie, word soms ook met die term "onderskei van" aangedui. Die semantiese verband is egter vaer as by die voorbeelde wat onder 5.5 gehanteer word met "Vgl.".

Louw (2000: 135) wys in navolging van Wiegand (1982: 133) daarop dat nie slegs sinonimie nie, maar ook ander semantiese verhoudings in 'n omvattende woordeboek met verskeie volumes, soos die WAT, aangedui behoort te word. Volgens Wiegand (1982: 133) is die aandui van sinonieme, naas die definisie, in eenvolume-handwoordeboeke (soos HAT) voldoende, maar antonimie, hiponimie en ander semantiese verhoudings behoort in omvattende woordeboeke apart van die betekenisverklaring gegee te word en duidelik aangedui te word deur ' $n$ unieke strukturele merker.

Oor die algemeen tree die WAT voorbeeldig op deur konsekwent alle lede van antoniem- en ander teenstellingspare in die dele wat reeds verskyn het, op te neem. By meerderjarig is daar byvoorbeeld 'n verwysing na minderjarig en omgekeerd. Daar is wel enkele uitsonderings by die steekproef aangetref. Die steekproef is gebaseer op die leksikale items in Müller (1989: 2795) in soverre dit in Afrikaans vertaalbaar is. By aankoms is daar nie 'n verwysing na vertrek nie. Dit geld ook die werkwoord aankom. By afstoot is daar 'n verwysing na 
aantrek, maar by aantrek is daar nie 'n verwysing na afstoot nie. By lag is daar 'n verwysing na huil, maar by huil is daar nie 'n verwysing na lag nie.

Teenstellings word ook soms in die definisie gehanteer, maar nie op die wyse soos aangedui in die toeligtingsgedeelte van die WAT deel XII, naamlik ingelei deur die woord "teenoor", nie. Dit is nie duidelik waarom die teenstelling hier gebruik word nie. Vergelyk in hierdie verband byvoorbeeld buitekant ten opsigte van die leksikale teenstelling:

buitekant. I s. Buitesy, die uitwendige van iets: Verf die kis net a/d buitekant.

Ook fig.: Iets net van die buitekant beskou, oppervlakkig.

II bw. Buite, nie binne nie: Wag jy solank buitekant tot die deur oopgaan.

III vs. Buite: Buitekant die huis is dit koud.

Soms word die teenstelling ook net in die voorbeeldsin(ne) genoem, bv. by binnekant waar dit die teenstelling illustreer:

Buitekant is dit koud, maar binnekant b/d vuur lekker warm.

Laasgenoemde verskynsel kom ook by die komplementêre teenstellende items voor. Vergelyk broer:

Ons is twee broers en drie susters.

En in enkele gevalle kom die teenstelling in 'n uitdrukking voor, bv. by huur:

Huur en verhuur, ooreenkoms waarby die een party a/d ander die genot van 'n saak gedurende ' $n$ beperkte tyd en teen 'n bepaalde prys afstaan.

In die toeligtingsgedeelte van die HAT word in 'n enkele sin onder andere oor antonieme berig:

Naas die betekenis, maar nie in die plek daarvan nie, word dikwels sinonieme gegee en, waar nodig, ook antonieme.

Hoewel die HAT nie in die toeligtingsgedeelte aandui hoe teenstellings gehanteer word nie, kom 'n mens gou agter dat 'n stelsel soortgelyk aan dié van die WAT, naamlik om "teenoor" te gebruik, ook hier van krag is. In 'n meerdere mate verskyn teenoorgesteldes dikwels slegs in die definisies. Vergelyk byvoorbeeld jonk, vars, maer, gesond, sag, dood, naby, lelik, passief, buitekant, ongesond, e.s.m. By ongesond kry 'n mens:

ongesond' b.nw. en bw. 1 Nie gesond nie; met 'n swak of verswakte gestel: ' $n$ Ongesonde kind, mynwerker. 2 Skadelik vir die gesondheid en die gees: 'n Ongesonde klimaat. 'n Ongesonde lewe lei. Ongesonde lektuur. 'n Ongesonde belangstelling in seks. 3 Nie gaaf nie: Ongesonde bome, vrugte.

Hier sou 'n verwysing na die spesifieke betekenisonderskeiding, naamlik gaaf ${ }^{3}$ duideliker leiding kon verskaf. 
In die toeligtingsgedeelte van die BWA word slegs gemeld dat kruisverwysings aan die einde van 'n paragraaf verskyn en gemerk word met die woord "teenoor". Die voorbeeld wat in die sleutel vir gebruikers gegee word, is: aanleer ... Teenoor: afleer.

Kruisverwysings kan om verskillende redes in woordeboeke gebruik word. Hulle kan die gebruiker byvoorbeeld waarsku dat daar verwante woorde is wat nie met die betrokke lemma verwar moet word nie. Hulle kan ook verwys na ander woorde wat meer inligting bevat. Duidelikheidshalwe behoort die samestellers te vermeld dat kruisverwysings slegs gebruik word om antonieme aan te dui en dat die kruisverwysings ingelei word deur die woord "teenoor" aan die einde van paragrawe. Alternatiewelik: Indien ander leksikale betrekkinge ook deur kruisverwysings geëkspliseer word, behoort die verwysings dienooreenkomstig gemerk te word.

Aanleerderwoordeboeke bevat gewoonlik 'n gekontroleerde, basiese woordeskat. Om hierdie rede kan 'n mens verstaan dat bepaalde laefrekwensiewoorde nie in die BWA opgeneem is nie. Vergelyk meerderjarig $\mathrm{x}$ minderjarig, minimaal $\mathrm{x}$ maksimaal en minimum $\mathrm{x}$ maksimum. Indien 'n woord soos aktief as lemma opgeneem is, is dit nie duidelik waarom die teenoorgestelde passief nie ook as lemma opgeneem is nie. Dit geld ook byvoorbeeld aantrek, maar nie afstoot nie, ondertoe, maar nie boontoe nie, meervoud, maar nie enkelvoud nie, oopmaak maar nie toemaak nie en afneem, maar nie toeneem nie.

Soms is beide teenoorgesteldes as lemmas opgeneem, maar die teenoorgestelde word net by een van die twee lede aangedui. So is daar byvoorbeeld by lelik ' $n$ aanduiding dat die teenoorgestelde mooi is, maar by mooi is daar nie 'n aanduiding van lelik as teenoorgestelde nie. Vergelyk ook oud $\mathrm{x}$ vars, siek $\mathrm{x}$ gesond, lewend $\mathrm{x}$ dood, swart $\mathrm{x}$ wit, manlik $\mathrm{x}$ vroulik, amateur $\mathrm{x}$ beroepspeler, toelaat $\mathrm{x}$ verbied, haan $\mathrm{x}$ hen (net in die voorbeeld genoem), en seun $x$ dogter (net in die voorbeelde genoem). Die voorbeeldmateriaal illustreer hier teenstellings wat slegs op bepaalde betekenisonderskeidings betrekking het.

Dit wil voorkom asof die BWA soms baie duideliker leiding gee as die WAT of die HAT. Vergelyk die lemma aanstaande. In sowel die WAT as die HAT word geen teenoorgesteldes aangedui nie. By die BWA word die volgende voorbeeldsinne gegee: "Hy kom aanstaande Maandag op die lughawe aan. Die aanstaande verkiesing beloof om baie interessant te wees. Aanstaande week gaan ons stad toe." Hierop volg dan die kruisverwysing, met 'n aanduiding van tipiese kollokators: "Teenoor: laas (Maandag, week), vorige (verkiesing)". Dit is net jammer dat daar nie by laas en vorige kruisverwysings na aanstaande en volgende is nie.

\subsection{Tweetalige woordeboeke}

In tweetalige woordeboeke (vgl. Hausmann 1991: 2794-2795) help sinonieme en antonieme met betekenisonderskeiding en teksproduksie en besit hulle ook 'n aanleerfunksie. Die hantering van teenstellings in Pharos se Afrikaans-Engels 
Woordeboek/English-Afrikaans Dictionary (Du Plessis 2005) (voortaan AEW) sal bespreek word in vergelyking met ander tweetalige Afrikaans-Engelse woordeboeke.

Wat die toeligtingsgedeelte betref, is daar 'n verbetering deurdat die AEW uiteensit hoe manlike en vroulike vorme in dié woordeboek gehanteer word. In vorige/ander tweetalige woordeboeke word dit nie aangedui nie. Daar word genoem dat manlike en vroulike vorme as afsonderlike lemmas opgeneem word en, waar nodig, van die etikette masc. (manlik) en fem. (vroulik) voorsien word. Die wyse waarop ander tipes teenstellingsbetrekkinge gehanteer word, word egter ook nie in die AEW verduidelik nie.

'n Seleksie van twee geslagsopposisiepare (vgl Beyer 1997: 108) met hul onderskeie vertaalekwivalente word vervolgens bespreek soos hulle telkens in AEW, die Tweetalige Woordeboek (Bosman, Van der Merwe en Hiemstra 1984) (voortaan TW), die Groot Woordeboek (Eksteen 1997) (voortaan GW) en die Tweetalige Aanleerderswoordeboek (Du Plessis 1993) (voortaan TA) gehanteer is.

Die eerste lemmapaar wat bespreek sal word, is: koning $x$ koningin teenoor king $x$ queen. In die bespreking word daar slegs gefokus op dié polisemiese waardes waar daar sprake is van geslagsopposisiepare. So staan koning en koningin glad nie in 'n geslagsopposisieverhouding ten opsigte van die betekeniswaarde "stuk in die skaakspel" nie, maar in 'n hiërargiese kontrastiewe verhouding (vgl. De Stadler 1989: 86-87).

In AEW word koning en koningin inderdaad as afsonderlike lemmas opgeneem en in dié twee lemmas se artikels word nie na die teenoorgestelde woord verwys nie. By king is daar wel 'n kruisverwysing na queen en by queen weer 'n kruisverwysing na king. Dit gee goeie leiding, aangesien king en queen alfabeties ver van mekaar verwyder is.

In die Afrikaans-Engelse deel van die TW is daar by die lemma koning nêrens 'n verwysing na die vroulike geslagsvorm koningin nie, selfs nie eers in die lys van vertaalekwivalente of die sublemmas van koning nie. Daar sou geredeneer kon word dat die insluiting van so 'n verwysing in die artikel van koning as oorbodig beskou kan word, omdat die lemma koningin direk onder die lemma koning gelys word. Dieselfde geld vir die lemma koningin waar daar ook geen verwysing na koning is nie. Dit is egter opvallend dat daar in die Engels-Afrikaanse deel, alhoewel nie eksplisiet nie, tog telkens 'n aanduiding van die komplementêre lid in beide die artikels se inskrywings onder king en queen verskaf word. Onder king word Queen en Queen's herhaaldelik in die voorbeeldmateriaal as teenstelling opgeneem, maar die aanbod daarvan is problematies, want volgens konvensie dui hakies ook op opsionele aanvullings. Kontekstueel gaan dit in die inskrywings ook oor wie die heerser is, en word die inskrywings dus nie noodwendig so aangebied om die opposisiebetrekking te impliseer nie. Dit kon byvoorbeeld ook "king (prince)" wees, wat 'n ander soort opposisieverhouding kan enkapsuleer.

Ten opsigte van die Afrikaans-Engelse deel bied die GW, anders as die TW, koning en koningin nie as aparte artikels onder mekaar aan nie. Die mor- 
fologiese verbuiging van koning na koningin word as 'n sublemma onder koning ingesluit.

In die Engels-Afrikaanse deel van die GW word daar weer eens, net soos in die geval van die Afrikaans-Engelse deel, geen kruisverwysings by die lemma, of sublemmas van king na queen gemaak nie. Daar is wel 'n potensieel implisiete verwysing by queenconsort na koning, mits die gebruiker weet om vors met koning as sinoniem te vervang. Vergelyk die volgende artikel:

queen, (n), koningin; vrou (kaart); koningin, dame (skaak); homoseksueel; [...] $\sim$ consort, vrou v.d. regerende vors; [...].

Daar is 'n bykomende probleem betreffende geslagsaanduiding in hierdie artikel van queen. Die vertaalekwivalent homoseksueel in die sinoniemparadigma, soos hierbo gelys, behoort geëtiketteer te word met byvoorbeeld ( $p e j .$, slegs manlike geslag). (Vgl. verder Gouws 1989: 243-244 in hierdie verband.) Die AEW tree hier voorbeeldig op deur queen soos volg te merk: (neerh. sl.: homoseksueel).

Koning en koningin word in die TA, soos ook in die mikrostruktuur van die TW, as twee afsonderlike artikels in die Afrikaans-Engelse deel onder mekaar geplaas. Hierdie teenstellingspaar is noodgedwonge in die Engels-Afrikaanse deel alfabeties uiteengeplaas Kruisverwysings kom egter nie in die TA voor nie, en dit is 'n ongelukkige tekortkoming van hierdie woordeboek, omdat aanleerders van 'n vreemde taal soveel te meer hulp met geslagsaanduiding behoort te ontvang, en waarskynlik hierop staatmaak.

Die volgende lemmapaar wat bespreek sal word, is: onderwyser $x$ onderwyseres teenoor teacher $x$ ø.

By die AEW is daar ' $n$ inkonsekwentheid met die hantering van die geslagsvorme wat deur middel van fleksieverbuiging gevorm word. Terwyl koning en koningin in die Afrikaans-Engelse deel, soos reeds vermeld, as twee afsonderlike lemmas gehanteer word, is dit nie die geval by onderwyser en onderwyseres nie. Onderwyseres word as 'n sublemma van onderwyser by die artikel ingeskryf. Dieselfde gebeur by die TW. Die geslagsopposisiepaar onderwyser $\mathrm{x}$ onderwyseres is 'n komplekse voorbeeld, want daar is ook sprake van die geslagtelik neutrale onderwyser. Die AEW en ander woordeboeke se hantering kan hier gekritiseer word, aangesien geensins vir die geslagtelik neutrale referent van die leksikale item onderwyser voorsiening gemaak word nie.

Die GW tree wel konsekwent op: in die Afrikaans-Engelse deel word weer eens 'n fleksieverbuigingsvorm es gebruik om die vroulike geslagsvorm in die artikel onder onderwyser as lemma aan te gee.

In die Afrikaans-Engelse deel sien die artikel soos volg daar uit:

onderwyser, (-s), teacher, instructor, educator; dominie; master, preceptor; es', (-se), teacher, mistress; [...]

In die eerste plek is daar geen pertinente aanduiding van die leksikale gaping wat daar in Engels ten opsigte van die vroulike geslagsvorm van teacher be- 
staan nie. Onderwyseres behoort gemerk te word met (female) vooraan teacher. Te oordeel na die uiteensetting van die woordeboekinskrywing soos hierbo weergegee, sal die gebruiker dalk wonder waarom master nie deel vorm van die eerste sinoniemparadigma nie en verder waarom dit nie met (school) vooraan gemerk is nie. Dieselfde geld vir mistress. Die woord mistress op sigself het nie juis positiewe konnotasies nie, gevolglik behoort (school) vooraan mistress gevoeg te word.

Die AEW hanteer onderwyser en onderwyseres wel inkonsekwent deurdat daar nie gehou word by die sisteem (volgens die toeligting) om aparte lemmas te gebruik nie, maar andersins is die uiteensetting baie duideliker as byvoorbeeld dié van die GW, hoewel daar nie voorsiening gemaak word vir die neutrale vorm onderwyser nie. Vergelyk:

onderwyser $=$ sers, $($ masc $)$ ), onderwyseres $=$ resse, $($ fem. $)($ school)teacher, $($ chiefly Br. $)$ (school)master (masc.), schoolmistress (fem.); [...]

Die TA lys die twee komplementêre leksikale items onderwyser en onderwyseres konsekwent onder mekaar as sublemmas in die Afrikaans-Engelse deel van die woordeboek en nie as aparte lemmas, soos deur De Wet (1998: 158) voorgestel word nie. De Wet (1998: 158) beveel aan dat die leksikograaf aan die Afrikaanse kant van die woordeboek dié pare geslagsgemerkte leksikale items waarvoor daar in Engels net een vertaalekwivalent is, as aparte lemmas opneem:

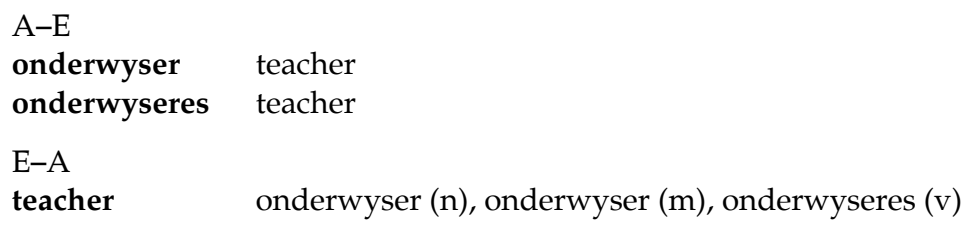

De Wet (1998: 158) wys verder daarop dat die volgorde waarin die vertaalekwivalente verskaf word, volgens die heersende leksikografiese praktyk, naamlik gebruiksfrekwensie, gedoen behoort te word. Dit beteken dat die woord wat die meeste gebruik word, eerste gegee behoort te word - en nie noodwendig die ongemerkte item nie. Vergelyk verder Beyer 1997: 107-115 vir die hantering van geslagsaanduiding.

\subsection{Eentalige antoniemwoordeboeke of sinoniemwoordeboeke met anto- nieme}

Hierdie tipe woordeboeke word gebruik om oplossings vir blokkiesraaisels te vind en vir teksproduksie deur sowel moedertaal- as niemoedertaalsprekers (vgl. Bergenholtz en Tarp 1995: 126). Waar onbekende lemmas verduidelik word deur meer bekende sinonieme of antonieme te gebruik, kan woordeboeke van sinonieme en antonieme ook as definiëringswoordeboeke dien. Dit gaan 
hier oor die onomasiologiese vs. die semasiologiese benadering tot die aanbod van betekenisinligting (vgl. Louw 2000).

Aangesien sinonieme en antonieme so nou met mekaar verband hou, is dit waarskynlik beter om beide in een woordeboek te hanteer, eerder as apart. Woordeboeke wat sinonieme (en antonieme) hanteer, se makrostrukture kan op twee verskillende maniere saamgestel word: die eerste metode is die alfabetiese of semasiologiese ordeningsmetode, waarvolgens die lemmas en hul aangebode sinonieme in alfabetiese orde aangebied word, en die tweede metode is dié van tematiese of onomasiologiese ordening, waarvolgens lemmas en hul aangebode sinonieme volgens bepaalde onderwerpe gerangskik word. Die voorbeelde (vir Engels) wat hieronder gebruik sal word, is Merriam-Webster's Collegiate Thesaurus wat gekontrasteer word met The Merriam-Webster Dictionary of Synonyms and Antonyms en laastens sal daar ook kortliks gewys word op die enigste Afrikaanse ekwivalent, naamlik die Afrikaanse Sinoniemwoordeboek met Antonieme deur Eksteen.

Terwyl die tesourus baie meer woordeskat aanbied, is die sinoniemwoordeboeke met antonieme meer gesteld daarop om byvoorbeeld vir 'n intermediêre aanleerder te help om tussen die verskillende sinonieme (en teenstellings) te onderskei. Die volgende voorbeelde van abandon (slegs as werkwoord hier aangehaal), eerstens uit Merriam-Webster's Collegiate Thesaurus en tweedens uit The Merriam-Webster Dictionary of Synonyms and Antonyms, illustreer dit baie duidelik. (Die inskrywing syn staan vir "synonym", idiom vir "idiomatic equivalent(s)", ant vir "antonym(s)", rel vir "related word(s)", con vir "contrasted word(s)", en //vir "use limited, if in doubt, see a dictionary".)

abandon $v b 1$. to give up without intent to return or reclaim <abandoned his family>

syn chuck, desert, forsake, quit, renounce, throw over

rel cast (off), discard, disuse, drop, junk, scrap; reject, repudiate

idiom have done with, leave, flat, quit cold, run out on, turn one's back on (or upon), walk out on

con hold, keep, possess, retain; redeem, rescue, save; acquire, gain, get, procure, win; cherish, foster

ant reclaim

2. syn RELINQUISH, cede, give up, hand over, leave, resign, surrender, // turn up, wave, yield

ant retain

abandon $v b$ 1. Abandon, desert, forsake mean to give up completely.

Abandon can suggest complete disinterest in the future of what is given up 〈they abandoned their cat at the end of the summer〉 ant reclaim

Desert implies a relationship (as of occupancy or guardianship): it can suggest desolation 〈deserted farms growing up to brush〉 or culpability 〈soldiers who desert their posts $>$ ant cleave to, stick to

Forsake implies a breaking of a close association by repudiation or renunciation 〈she forsook her husband for a career〉 ant return to, revert to

2. see RELINQUISH 
Vergelyk ook die volgende voorbeeld uit die Afrikaanse Sinoniemwoordeboek met Antonieme deur Eksteen, waar daar by 'n groot aantal lemmas ná die sinonieme en hiponieme ook teenstellingswoorde gegee word. Dié teenstellingswoorde verskyn na 'n vierkantige blokkie en is kursief gedruk om hulle van die res van die artikel te onderskei. Vergelyk die volgende voorbeeld:

eggenoot: man, huweliksmaat, huweliksgenoot, lewensgesel, wederhelf, gemaal, beste, ou beste, ega, gade

eggenote, vrou, gemalin

\section{Slot}

Paradis en Willners (2006) het die hantering van antonimie in die Collins COBUILD Advanced Learners' English Dictionary (2003) (voortaan CCALED) volledig ondersoek. Hulle wys eers op positiewe aspekte soos die praktiese voordeel wat hierdie woordeboek bo die meeste ander woordeboeke het deurdat leksikale verhoudinge in die kantlyn gespesifiseer word en daarom maklik raakgesien en ontsluit kan word. Verder kom hulle tot die gevolgtrekking dat daar duidelike ooreenkomste is betreffende die betekenisse van die lemmas wat gedefinieer word deur antonieme: Hulle is almal inherent binêr en hulle is saamgestel volgens 'n skaal of grens. Die meerderheid lemmas met antonieme is adjektiewe. Dit is egter nie vir hulle duidelik watter beginsels gegeld het by die opname van antonieme nie, aangesien sommige leksikale items nie van antonieme voorsien is nie. Volgens hulle is een van die hoofoogmerke van ' $n$ aanleerderswoordeboek soos die CCALED om leerders te begelei in hul pogings om 'n goeie greep op die struktuur van die woordeskat van 'n vreemde taal te kry. Aangesien die CCALED 'n korpusgebaseerde woordeboek is, behoort dit gebruik te maak van die inligting wat onttrek kan word uit die korpus. Hulle stel 'n volledige en prinsipiële gebruik van die korpus voor. Een van die maniere waarop die korpus volgens vaste beginsels gebruik kan word, is deur rekenaarprogramme soos Coco.

Volgens Justeson en Katz (1991) en Jones (2002) is dit 'n welbekende feit dat antonieme meer gereeld in sinne verskyn as wat voorspel sou kon word. En kanonieke antonieme kom meer dikwels saam voor as kontekstueel beperkte antonieme (vgl. Willners 2001). Paradis en Willners (2006) meen dat hierdie toedrag van sake 'n waardevolle wenk verskaf oor watter antonieme geselekteer en in 'n woordeboek ingesluit behoort te word. Willners (2001: 83) en Holtsberg en Willners (2001) het 'n rekenaarprogram genaamd Coco ontwikkel om verwagte en waargenome saamvoorkomende woorde in sinne in 'n gegewe lys in terme van waarskynlikheid te bepaal. Coco is ook ontwerp om sinslengtevariasie in ag te neem, wat 'n verbetering was in vergelyking met die studie deur Justeson en Katz (1991). Met behulp van Coco het Willners die adjektiewe in die Sweedse korpus ('n miljoenwoordkorpus) ondersoek. Die studie het alle adjektiewe in die korpus wat meer as vyf keer verskyn, ingesluit en het aangetoon dat 357 van die adjektiefpare beduidend meer as voorspel sou word, saam 
voorgekom het op 'n beduidendheidsvlak van $10^{-4}$. Woordeboeke sou baat kon vind by die bepaling van die mees frekwente antoniempare, aangesien sommige woordeboeke nie die ruimte het om alle teenstellings te akkommodeer nie. Verder kan hierdie instrument help om te verseker dat minstens die mees frekwente teenstellings wel konsekwent aangedui word.

Leksikograwe behoort veel meer aandag te skenk aan teenstellings in verskillende tipes woordeboeke, veral omvattende woordeboeke en aanleerderwoorde. Dit kan gedoen word deur 'n korpusgerigte benadering soos hierbo aangetoon. Teenstellings moet duidelik deur 'n unieke strukturele merker aangedui word. Die metode vir die hantering van teenstellings waarop die leksikograaf besluit, moet dan ook konsekwent gehanteer word in die woordeboek.

\section{Bibliografie}

\section{Woordeboeke}

Bosman, D.B., I.W. van der Merwe en L.W. Hiemstra. 1984 ${ }^{8}$ Tweetalige Woordeboek/Bilingual Dictionary. Kaapstad: Tafelberg.

Du Plessis, M. 1993. Tweetalige Aanleerderswoordeboek/Bilingual Learner's Dictionary. Kaapstad: Tafelberg.

Du Plessis, M. (Hoofred.). 2005. Pharos Afrikaans-Engels Woordeboek/English-Afrikaans Dictionary. Kaapstad: Pharos Woordeboeke.

Eksteen, Louis. 1983. ASA Afrikaanse Sinoniemwoordeboek met Antonieme. Pretoria: J.L. van Schaik.

Eksteen, L.C. 1997. Groot Woordeboek Afrikaans-Engels/Engels-Afrikaans/Major Dictionary AfrikaansEnglish/English-Afrikaans. Kaapstad: Pharos.

Gouws, Rufus, Ilse Feinauer en Fritz Ponelis. 1994. Basiswoordeboek van Afrikaans. Pretoria: J.L. van Schaik.

Merriam-Webster's Collegiate Thesaurus. 1994. Springfield: Merriam-Webster.

Odendal, F.F. en R.H. Gouws (Reds.). 2000. Verklarende Handwoordeboek van die Afrikaanse Taal. Midrand: Perskor.

Sinclair, J. (Red.). 20034. Collins COBUILD Advanced Learner's English Dictionary. Glasgow: Harper Collins Publishers.

The Merriam-Webster Dictionary of Synonyms and Antonyms. 1992. Springfield: Merriam-Webster.

Woordeboek van die Afrikaanse Taal. 1950-. Pretoria: Die Staatsdrukker.

\section{Algemeen}

Bergenholtz, H. en S. Tarp (Reds.). 1995. Manual of Specialized Lexicography. Amsterdam: John Benjamins.

Beyer, Herman L. 1997. Aard en leksikografiese hantering van sogenaamde geslagtelik neutrale lede van Afrikaanse geslagsopposisiepare. S.A. Tydskrif vir Taalkunde 15(4): 107-115.

Cruse, D.A. 1986. Lexical Semantics. Cambridge: Cambridge University Press.

De Stadler, L.G. 1989. Afrikaanse semantiek. Johannesburg: Southern. 
De Wet, Gerda. 1998. Die makrostrukturele vergestalting van affikse en tegnostamme in Afrikaanse vertalende woordeboeke. Lexikos 8: 154-172.

Feinauer, A.E. 1996. Die negende deel van die Woordeboek van die Afrikaanse Taal. Lexikos 6: 233-271.

Gouws, R.H. 1989. Leksikografie. Pretoria: Academica.

Gouws, R.H. 1990. Information Categories in Dictionaries, with Special Reference to Southern Africa. Hartmann, R.R.K. (Red.). 1990: 52-65.

Halliday, M.A.K. en R. Hasan. 1976. Cohesion in English. Harlow: Longman.

Hartmann, R.R.K (Red.). 1983. Lexicography: Principles and Practice. Londen: Academic Press.

Hartmann, R.R.K. (Red.). 1990. Lexicography in Africa. Progress Reports from the Dictionary Research Centre Workshop at Exeter, 24-25 March 1989. Exeter Linguistic Studies 15. Exeter: Exeter University Press.

Hausmann, F.J. 1991. Die Paradigmatik im zweisprachigen Wörterbuch. Hausmann, F.J., O. Reichmann, H.E. Wiegand en L. Zgusta (Reds.). 1989-1991: 2794-2795.

Hausmann, F.J., O. Reichmann, H.E. Wiegand en L. Zgusta (Reds.). 1989-1991. Wörterbücher. Ein internationales Handbuch zur Lexikographie/Dictionaries. An International Encyclopedia of Lexicography/Dictionnaires. Encyclopédie internationale de lexicographie. Handbücher zur Sprach- und Kommunikationswissenschaft 5.1-5.3. Berlyn/New York: Walter de Gruyter.

Holtsberg, A. en C. Willners. 2001. Statistics for Sentential Co-occurrence. Working Papers Lund, Sweden: Department of Linguistics, Lund University 48: 135-148.

Jones, S. 2002. Antonymy: A Corpus-based Perspective. Amsterdam: Routledge.

Jones, S. 2006. The Discourse Functions of Antonymy in Spoken English. Text and Talk 26(1).

Justeson, J.S. en S.M. Katz. 1991. Co-occurrences of Antonymous Adjectives and their Contexts. Computational Linguistics 17: 1-19.

Lehrer, A. 1985. Markedness and Antonymy. Journal of Linguistics 31(3): 397-429.

Lehrer, A. en K. Lehrer. 1982. Antonymy. Linguistics and Philosophy 5: 483-501.

Louw, Phillip. 2000. An Integrated Semasiological and Onomasiological Presentation of Semantic Information in General Monolingual Dictionaries as Proposed in H.E. Wiegand's Semantics and Lexicography. Lexikos 10: 119-137.

Lyons, J. 1977. Semantics. Cambridge: Cambridge University Press.

Moulin, A. 1983. The Pedagogical/Learner's Dictionary. II LSP Dictionaries for EFL Learners. Hartmann, R.R.K. (Red.). 1983: 144-152.

Muehleisen, V. 1997. Antonymy and Semantic Range in English. Ph.D.-tesis. Evanston, IL: Northwest University.

Müller, W. 1989. Die Antonyme im allgemeinen einsprachigen Wörterbuch. Hausmann, F.J., O. Reichmann, H.E. Wiegand en L. Zgusta (Reds.). 1989-1991: 2794-2795.

Nation, I.S.P. 2001. Learning Vocabulary in Another Language. Cambridge: Cambridge University Press.

Palmer, F.R. 1976. Semantics. Cambridge/Londen: Cambridge University Press.

Paradis, C. en C. Willners. 2006. What a Corpus-based Dictionary Tells Us about Antonymy. Referaat gelewer by die Twaalfde EURALEX Internasionale Kongres, 6-9 September 2006, aangebied deur die Fakulteit Moderne Tale en Literatuur en die Departement Lettere en Filologie van die Universiteit van Turyn, Italië, saam met die Accademia della Crusca.

Raidt, Edith H. 1993. Die agtste deel van die Woordeboek van die Afrikaanse Taal. Lexikos 3: 215-226. 
Wiegand, Herbert E. 1982. On the Meaning Explanation of Sentence Adverbs in Monolingual Dictionaries. Wiegand, Herbert E. 1999: 113-138.

Wiegand, Herbert E. 1999. Semantics and Lexicography. Selected Studies (1976-1996). Redaksioneel versorg deur Antje Immken en Werner Wolski. Tübingen: Max Niemeyer.

Willners, C. 2001. Antonyms in Context. A Corpus-based Semantic Analysis of Swedish Descriptive Adjectives. Travaux de l'Institut de Linguistique de Lund 40. Lund, Sweden: Department of Linguistics, Lund University. 